\title{
The Area And Aspects of Polish ANd German STUdies ON PUbliC AdMINistration
}

\author{
MAGDALENA TABERNACKA*
}

A goal, a purpose and a foundation - these three categories define the scope of any scientific or scholarly research. Hence, the field of investigation.

A need or necessity compelling a scholar to undertake a study evolves from certain facts, certain objective states of reality which are to be assessed and evaluated. In the case of Polish and German scholarship the main underlying fact is the neighbourship of the two countries with any and all social consequences which may stem from this state of things and exert an impact on the operating choices made by the bodies of public administration on both sides of the border.

The academic studies both in administrative law and administration conducted in Poland or Germany do not see differences as regards the role of the public administration bodies under the rule of the democratic state of law. The bodies of public administration in this type of polity are treated as elements of the law enforcement power. Therefore, in Poland or Germany, their competences include acting in their capacity of public task providers, which in practice means that they cater for the needs of individuals and communities ${ }^{1}$. Where public tasks are carried out in two neighbouring states with an intense interaction and exchange between the two communities, a common procedural policy let alone a set of shared rules with a significant legal impact must be developed. Business or commerce are not the exclusive spheres necessitating such steps. There is the entire social area where public administration entities are entrusted with a range of duties such as family relationships, children born to binational parents or single nationality foreign families who have settled in the neighbouring country. One inevitably deals with all kinds of policies which can be denoted as administrative policy understood, according to Jan Jeżewski, as the policy in line with which the administration engages in the different areas of its competence to execute statutory public tasks, set goals, establish priorities, plan for executive measures and implementation methods and predict

\footnotetext{
DOI: $10.1515 /$ wrlae-2015-0047

* PhD in Law with a post-doctorate degree in Law, Assistant Professor at the Institute of Administrative Sciences, Faculty of Law, Administration and Economics, University of Wrocław; magdalena.tabernacka@uwr.edu.pl

${ }^{1}$ Definition of public responsibility: Jan Boć, 'Prawo administracyjne' [Administrative law] (Kolonia Limited 2010) 15.
} 
outcomes, all of which is termed by the author as: administration policy ${ }^{2}$. These policies call for a set of common rules and shared coordination, which appears particularly important for environmental protection in the broad sense of the phenomena and the implementation of different EU policies. A common operating platform determines a need for common research efforts made "together" or through parallel programmes launched on both sides of the border with shared goals to tackle the same range of problems from the perspectives of each state.

A multicultural perspective is the main factor to be considered in determining the lines of the Polish and German research on the operating conditions and methods of public administration. It pertains to the impact exerted on the administration by the society seen as its environment and to the administration itself, or to be precise, its organisation culture followed by its bodies and units that conditions the actions and conduct of individuals who are employed there.

In every state or its sub-structure, public bodies operate according to a set pattern known as a culture of the public administration system. It evolves as a consequence of the interacting historical, political and sociological processes and at the same time is naturally a product of the law. Cultural differences do not only lie in the arrangement of organisational structures or the distribution of power but also in a degree of formality maintained in the relationships between civil servants and local authority officers, on the one hand, and public administration staff, on the other hand or the type and form of liaisons, communication protocols or etiquette when it comes to showing interpersonal respect and courtesy ${ }^{3}$. It is worth noting that operating within one legal and administrative culture inevitably leads to ethnocentrism. As a driver of social processes, law influences the mentality of its individual subjects just like the method of exercising state power influences their behaviours and perceptions of their individual places in the society ${ }^{4}$. Therefore Polish and German studies in public administration should also account for any operational and organisational ethnocentrism of public administration. This means a scholarly duty to investigate the historically conditioned social sphere underlying certain phenomena though not necessarily tackling the "big issues" relating to the historical past of the two countries or the interests of the state as the community. Social culture affects different aspects of the operation of individual administration systems ${ }^{5}$. It is important to bear this fact in mind while analysing certain universal mechanisms.

2 Jan Jeżewski, 'Polityka administracyjna. Zagadnienia podstawowe' [Politics of Administration. The basics problems] in Adam Baś, Jan Boć, Jan Jeżewski (eds), Nauka Administracji [Science of Administration] (Kolonia Limited 2013) 314.

${ }^{3}$ Magdalena Tabernacka, Negocjacje i mediacje $w$ sferze publicznej [Negotiations and mediations in public sphere] (Wolters Kluwer 2009) 153-154.

4 Magdalena Tabernacka, 'Etnocentryzm w obszarze działania władz publicznych' [Ethnocentrism in the area of public authorities activity] in Artur Preisner (ed), Czy istnieje uniwersalny standard praw człowieka? Kulturowe i cywilizacyjne uwarunkowania statusu jednostki [Is there a universal standard of human rights? Cultural and civilizational conditioning of the status of an individual] (2013) 3 Zeszyty Luksemburskie 281.

${ }^{5}$ For example, the education system in Germany and Poland has been and is being shaped in specific social, demographic and economic conditions. Geographical conditons are also not without significance. This combination of factors influences such specific issues as, 
A multicultural perspective in public administration research does not imply that studies should focus on the homogenisation of administrative and legal solutions. This perspective is necessary to understand the purpose, motives and special modes of operation followed by the administrative bodies on both sides of the border. Only with this knowledge may one embark on designing theoretical models for further practical application in mutual contacts. Therefore, it is imperative that scholars allow for flexible ethnocentrism in the comparative approach to administration. In their research on flexible ethnocentrism David Matsumoto and Linda Juang reached the conclusion that what is required to develop a flexibility in contact with other people and maintain one's ethnocentrism is one's awareness of one's own cultural filters and one's understanding the fact that members of other cultures have different cultural filters with each culture holding a strong belief that its version of reality is the true and correct one. The authors also emphasise that flexible ethnocentrism does not mean one's acceptance of a newly explored perspective. It means understanding the new ${ }^{6}$.

Evaluation seems unavoidable in multicultural studies. And, bearing in mind a complex history and practicalities of mutual interdependence, it is essential for Polish and German relationships. Multicultural studies are also profoundly influenced by the phenomenon known as attributive asymmetry, which equally affects the research on public administration in Germany and Poland. Paweł Boski notes that the essence of scholarly thinking (reasoning) is explaining and predicting observed (or discovered) phenomena. And this is the background against which he analyses the subjective assessment of success and failure. In accordance with the effect of attributive asymmetry abilities and effort are the two main causative categories explaining one's success, but their importance declines if one evaluates one's failure. If one's failure follows someone else's success it will not be attributed to these features to the same rather high degree. Interestingly, a third party's success following our own triumph is explained by lack of ability and effort on the part of such people. It appears that one's success may become set off by an interpretation of a third party's failure in way that is favourable to I whilst one's failure can be interpreted to reduce the success of other people ${ }^{7}$.

The research on the functioning of the administration in Poland and Germany and its effects has to account for these important interdependencies. The reason being, that the scope of studies on the two systems is defined by the common goals of the single Europe and the pragmatic communality and interdependence of the neighbourship.

e.g., school holidays, whose temporal distribution is substantially different in the two countries. There is no autumn break in Poland, but it "naturally" emerged in Germany or Italy because of the need for children to be involved in field labor at that time. In Poland such practices were no longer in place after the partitions and significant transformations of the state. Institutions, procedures and ways of acting needed unification and the entire state was "re-established" without preserving local customs and practices that were different in different parts of the country.

${ }^{6}$ David Matsumoto, Linda Juang, Psychologia międzykulturowa [Culture and Psychology:

People Around the World] (Gdańskie Wydawnictwo Psychologiczne 2007) 90-91.

${ }^{7}$ Paweł Boski, Kulturowe ramy zachowań społecznych. Podręcznik psychologii międzykulturowej [Cultural framework of social behavior. Handbook of Intercultural Psychology] (Wydawnictwo Naukowe PWN, Academica Wydawnictwo SWPS 2009) 296. 
Interdependence and a common goal fall into the category of the conditions of the effective contact so called by Aronson, Wilson and Akert. They further assign equal status, informal interpersonal contacts, multiple contacts with members of an alien group and social norms of equality to this category ${ }^{8}$. It is worthwhile emphasising certain specific determinants which influence the relationship between the states and their administrations and the inhabitants and citizens of Poland and Germany. The research should, on the one hand, tackle all measurable facts which, for example, can be expressed in economic and quantifiable categories and on the other, it should give account of subjective social conditions, including the social perception of certain phenomena. Administration is an activity of the people employed by the state's structures for the benefit of the people who create the state. This is the context which makes Marion von Dönhoff's words sound very relevant and adequate when she writes that the course of history is determined by how people subjectively imagine facts rather than objective facts themselves. ${ }^{9}$ There are certain phenomena in the life of the society and the functioning of institutions which meet the criteria of such determinants in particular for the functioning of the administration in the two countries. Therefore they should become a subject of the currently conducted research and future updates. They should also be included in the background studies for the research on certain detailed topics which I will list in the subsequent sections of this paper.

One of specific phenomena which is described in literature and calls for an in-depth study is the so called asymmetry between the economic system, the social systems and the administration systems of the two states. A multifaceted analysis of this phenomenon has been completed by Kazimierz Wóycicki and Waldemar Czachór. According to these authors the actual proportions are not as clear as is generally believed in such areas as the level of education seen as the country's potential and the economic growth, allowing for the obvious fact that Germany is a much wealthier country. The authors believe that the notion of asymmetry should not be ignored. Nonetheless it should not be overemphasised. As one invokes and allows for asymmetry in one's work one should measure real proportions rather than apply stereotypes ${ }^{10}$. Asymmetry shares much in common with the ethnocentric approach to the Polish and German problems. Importantly, it may determine any assessment or evaluation of a situation by Polish scholars as much as German ones. And there is a clear connection with the stereotypes adopted on both sides of the border. The ethnocentrism of the academia on both sides of the border may only be overcome through the knowledge about the popular and stereotypes which are cultivated by academia itself as opposed to the reality.

\footnotetext{
${ }^{8}$ Elliot Aronson, Timothy D. Wilson, Robin M. Akert, Psychologia społeczna [Social Psychology] (Zysk i S-ka 2006) 380.

${ }^{9}$ Marion von Dönhoff, 'Europejski dom' [European Home] in Alice Schwarzer, Marion Dönhoff. Życie pod prąd (Wydawnictwo książkowe Twój Styl 1999) 158.

${ }^{10}$ Kazimierz Wóycicki, Waldemar Czachór, Jak rozmawiać z Niemcami? O trudnościach $w$ dialogu polsko-niemieckiego i jego europejskim wyzwaniu [How to talk with German. About Polish-German dialogue and its European Challenge] (Oficyna Wydawnicza Atut 2009) $31-38$.
} 
Hence a capital meaning of all research and studies which involve the confronting of positive as much as negative stereotypes with the objective information and the identifying of the stereotype perceptions of Poles by Germans and Germans by Poles and other issues which are of a key importance for the cross-border exchange. The "Barometr PolskaNiemcy" - "Poland-Germany Barometer" is an example of this type of project ${ }^{11}$. The most recent edition of the project provides a range of opinions which seem influential for the perception of the Polish and German problems by scholarly circles and are instrumental for the functioning of the administration in the mutual contacts. The published report shows that more or less a half of the population surveyed in both countries have neutral associations with the neighbouring country. Furthermore, Poles see the situation in Germany in a very positive way. They preserve an especially good view of the German economy but good work organisation has suffered a setback (9 per cent points) as much as a belief in the good development of the German economy ( 8 per cent points). Meanwhile the proportion of those who can see corruption and bureaucracy in Germany has grown ( 9 per cent points in either case), which, according to the author of the report, may echo the immigration crisis, the impact of the political elite's opinions in Poland and the "disenchanting" of Germany due to an improved situation in Poland. Nonetheless, Poles appreciate the work organisation and a return of capital on an investment in Germany. Germans reciprocate this with a positive view of the economic growth in Poland (in fact this score has dropped by 4 per cent points since 2013) and appreciate Poland as a tourist destination. At the same time their belief that Poland suffers from corruption and the country's bureaucracy hinders business dealings. Germans have a negative view of the work organisation and media freedom in Poland. Public opinion in Germany has responded to the recent developments in Poland; opinion has become less favourable as regards: the freedom of the media in the criticism of the national government (17 per cent points), respecting civil freedoms (12 per cent points), respecting the rights of national and ethnic minorities ( 8 per cent points) and the functioning of parliamentary democracy (13 per cent points). What prevails when Poles evaluate Germany is a good opinion of the democratic system of government, respecting civil liberties and respecting the rights of national minorities. The appreciation and liking taken by Poles to Germans has been much stronger than the reciprocal feelings on the German part. In 2016, 53 \% Poles declared that they liked Germans with $28 \%$ Germans reciprocating the same attitude. Poles were seen in a hostile way by $36 \%$ Germans with $14 \%$ Poles declaring a negative view of Germans ${ }^{12}$. These results are of key importance both for the functioning of administration and for motivating scholars and their

\footnotetext{
11 These studies are the result of cooperation between the Institute of Public Affairs and the Konrad Adenauer Foundation. The aim of this project is to systematically study and present the opinions of Poles and Germans on Polish-German relations and the challenges that these countries are facing.

${ }^{12}$ Agnieszka Łada in cooperation with Jacek Kucharczyk and Gabrielle Schöler, Barometr Polska - Niemcy 2016. Polacy i Niemcy o sobie nawzajem 25 lat po podpisaniu traktatu o dobrym sąsiedztwie i przyjaznej wspótpracy [The Barometer Poland-German. Poles and Germans about each other 25 years after sign Treaty on the good Neighbourhood and Friendly Cooperation'].

See: http://www.isp.org.pl/barometr2016/pl/Barometr_2016_pl.pdf
} 
developing their opinions. Every human activity should always allow for human nature, part of which is also emotions. Todd D. Nelson refers to rather obvious fact that intergroup interactions comprise an emotional component. Emotions lead to distortions and errors in information processing and enhance the observer's inclination to use stereotypes during the processing of the information about the member of the alien group in the group context ${ }^{13}$.

The above described asymmetry in the evaluations provided by Poles and Germans and the mutual stereotyping are to some extent related with a phenomenon present on the German side. This phenomenon has been identified by Kazimierz Wóycicki and Waldemar Czachór and seems rather instrumental for Polish and German liaisons and research. The two authors have defined it as the deficit of respect or a certain under-appreciation of the nature of Polish efforts and endeavours to reach the current point in its political, economic and social development over the last few decades. The authors believe that respecting one's partner means learning from the partner and a willingness to engage into multifaceted collaboration, which does not exclude an eventuality of conflict ${ }^{14}$. This is not merely about Polish and German relations but the German West-bound orientation (except for the special relationship with Russia), which was noted by Marion von Dönhoff when she wrote of the old conviction that lingered between 1920s and 1960s among German elites who believed that the culture existed in the West only. The author wrote that the world as seen by Germans of the day was identical with the West. This was the place where Germans were capable of engaging in politics with panache, rouse their imagination to integrate and reconcile with old enemies. But this world would end at the iron curtain ${ }^{15}$. The German policy towards the East and Poland has radically changed since that era. A fading trait of this orientation has remained until today. It is still discernible even in the Barometer report and is, in particular, revealed in the survey of the German appreciation and liking to the inhabitants of the different European countries ${ }^{16}$.

The special Polish and German cultural context of the public administration studies should allow for a broad spectrum of cultural interdependencies rather than a single isolated problem reduced to a range of specific recent stereotypes. All fields where culture affects human perception must be considered. This is a treatment and observations offered by Sławomir J. Magala in his a model of cross-culture competences. As part of the tasks for academia the author has designed his model to comprise decoding and comparing cognitive, relative and emotional codes ${ }^{17}$. These are certainly platforms where culture affects social relationships and the functioning of individuals, which also concerns public administration staff. Consequently, the Polish and German studies on public administration

13 Todd D. Nelson, Psychologia uprzedzeń [Psychology of Prejudice] (Gdańskie Wydawnictwo Psychologiczne 2003) 96.

${ }^{14}$ Wóycicki, Czachór (n 11) 55.

15 Marion von Dönhoff, 'Nie mamy polityki wschodniej' [We don't have the East Politics] in Schwarzer (n 10) 190.

${ }^{16}$ Lada (n 13) 24-25.

${ }^{17}$ Sławomir J. Magala, Kompetencje międzykulturowe [Cross-Cultural Competence] (Wolters Kluwer 2011) 55. 
cannot fail to ignore any factors which determine the mutual liaisons from the communication angle or affect the mutual perception and evaluation inclusive of the emotional sphere. Kazimierz Wóycicki and Waldemar Czachór quote quite a compelling example that skilfully illustrates the situation: it is a Polish custom that when you strike up a conversation you begin with a routine banter about your own weaknesses. Your partner in conversation is expected to respond with the same self criticism. The authors note that when the other party is German, who has just heard a Pole highlighting his or her vices, there is no chance for self-ridicule from the German side. He or she will just comfort the Pole with a perspective of fighting such imperfections of one's character. The result is that Poles generally consider Germans bores with no sense of humour or arrogant people $^{18}$.

The research on Polish and German administration should also account for the cross-border areas in both countries and tackle its special aspects: business, societal issues, demographics and structural problems. Kazimierz Wóycicki and Waldemar Czachór emphasise such topics as a need for business stimulation and incentives of the cross-border territories with a stress on the economically disadvantaged areas on the German side ${ }^{19}$, which gives the Polish partner a slight edge over the German one. However, the ultimate result would be to mutual benefit. The authors emphasise a range of problems relating to the operation of administrative bodies including, but not limited to, slimming down the bureaucracy required by German entrepreneurs launching their businesses in Poland and the xenophobic bureaucracy that appears to be ignorant of the special Polish and German coexistence in Germany; training and education of local authorities and the "regional foreign policy" 20.

The Barometer shows a rather positive trend both in terms of the bilateral relations in the future and the so called climate for academic research, namely the residents of the eastern Länder see the Polish and German relations in a more positive light than those who live in western Länder. The people from the eastern states will also more often advocate collaboration with Poland that the inhabitants of the western states ${ }^{21}$. Frequent mutual contact helps to break negative stereotypes. Therefore this positive attitude of the German communities living in the East of Germany may bear fruit by creating a form of sustainable Polish and German relations of scale. The need for administration studies is not limited to the systems operated in eastern Länder although the situation on the frontier is always crucial for all bilateral contacts both at the local level and on the national scale in the context of the overall public administration systems.

The current status of the studies on Polish and German administration is a result of an impressive and highly commendable effort that has been made in the field of social science for several decades now.

\footnotetext{
${ }^{18}$ Wóycicki, Czachór (n 11) 118.

${ }^{19}$ This pertains in particular to a phenomenon referred to as the merger of the West German tenency for overregulation and learned helplessness, which, in the context of the postsocialist history of the region, is called "ostdeutsche Wirtschaft " on analogy to a still lingering cliched term "polnische Wirtschaft".

${ }^{20}$ Wóycicki, Czachór (n 11) 93-100.

${ }^{21}$ Łada (n 13) 43, 54.
} 
The work has involved a broad spectrum of historical developments, practical liaisons, mutual interdependences, conditions and a multifaceted social dialogue between Poland and Germany. Those were decades of commitment with the aim of understanding the essence of the coexistence of Germans and Poles in Europe and forming its axiological and legal foundations. The work on the extended sphere of Polish and German relations and contributions from such personalities as Stanisław Stomma, Władysław Bartoszewski, Marion von Dönhoff brought forwards the status of the research on the functioning of administration. The phase of searching for ways to start a dialogue is part of the past. The studies are currently conducted in a common context. The shared research platform is the communality and community of goals. This is a fact and it calls for description and findings to ensure the compatibility and efficiency of the operation of pubic administrative structures and procedures which facilitate the functioning of administration.

The studies on Polish and German administration should focus on those organisational and functional aspects which are instrumental for the necessary collaboration between the administration bodies and where one party responds to the activities of the other. There are a number of areas of competence allocated to public administration bodies, e.g. family matters inclusive of an opportunity for mediations. This field of scholarly studies should allow for child custody and an analysis of the bodies responsible for family support in terms of bringing up and educating children and providing for foster care. There is also a broad and important area of environmental protection as a task for administration bodies on both sides of the border. The research should offer them a proposal of a system and operating methods. The collaboration between the police forces, fire departments and other services are another example of research opportunities as all of them are legally bound to respond to emergencies and disasters in a way that is significant for the communities both in Poland and Germany.

As part of Polish and German academic efforts there should be room for teaching programmes on the national systems of law and public administration, the mechanisms of communication among the units in the public administration structures, special aspects and etiquettes used for the purpose of customer contacts or a wide-scale public administration targets or service recipients. All research and studies should be conducted in the "cross-border" perspective and on the restricted scale with a single, Polish or German, administration and legal system in focus. Nonetheless, such studies must not ignore any important spheres between the two systems where one system may react in response to the activities or operation of the other and result in certain consequences also as part of the cross-border contacts.

All academic research should allow for the perspective of a rolling horizon. There are no fixed and permanent relationships in the social sphere. And both public administration and the scholars concerned with it should be prepared to accept this device. Once established, all may become irrelevant if a situation changes as a result of any earlier developments. This is a never ending story. In the case of the Polish and German studies on public administration, the fixed points are the facts of the neighbourhood and the 
resulting social contacts in certain political, demographic and economic circumstances. What is important is that in the situation of the inevitable cultural differences, the administrations of the two countries have been taking steps in the sphere of human needs which do not appear to be of a different nature. The only difference lies in the methods of operation and cooperation dictated by the different circumstances. This is the condition that triggers the continuity of research in the common Polish and German perspective.

\section{References}

Aronson Elliot, Wilson Timothy D., Akert Robin M., Psychologia społeczna [Social Psychology] (Zysk i S-ka 2006)

Boć Jan., 'Prawo administracyjne' [Administrative law] (Kolonia Limited 2010)

Boski Paweł, Kulturowe ramy zachowań społecznych. Podręcznik psychologii międzykulturowej [Cultural framework of social behavior. Handbook of Intercultural Psychology] (Wydawnictwo Naukowe PWN, Academica Wydawnictwo SWPS 2009)

Dönhoff Marion von, 'Europejski dom' [European Home] in Schwarzer Alice, Marion Dönhoff. Życie pod prąd (Wydawnictwo książkowe Twój Styl 1999)

Dönhoff Marion von, 'Nie mamy polityki wschodniej' [We don't have the East Politics] in Schwarzer Alice, Marion Dönhoff. Życie pod prąd (Wydawnictwo książkowe Twój Styl 1999)

Jeżewski Jan, 'Polityka administracyjna. Zagadnienia podstawowe' [Politics of Administration. The basics problems] in Baś Adam, Boć Jan, Jeżewski Jan (eds), Nauka Administracji [Science of Administration] (Kolonia Limited 2013)

Łada Agnieszka, in cooperation with Jacek Kucharczyk and Gabrielle Schöler, Barometr Polska - Niemcy 2016. Polacy $i$ Niemcy o sobie nawzajem 25 lat po podpisaniu traktatu o dobrym sasiedztwie i przyjaznej wspótpracy [The Barometer Poland-German. Poles and Germans about each other 25 years after sign Treaty on the good Neighbourhood and Friendly Cooperation'].

See:

http://www.isp.org.pl/barometr2016/p1/Barometr_2016_pl.pdf

Matsumoto David, Juang Linda, Psychologia międzykulturowa [Culture and Psychology: People Around the World] (Gdańskie Wydawnictwo Psychologiczne 2007)

Nelson Todd D., Psychologia uprzedzeń [Psychology of Prejudice] (Gdańskie Wydawnictwo Psychologiczne 2003)

Tabernacka Magdalena, 'Etnocentryzm w obszarze działania władz publicznych' [Ethnocentrism in the area of public authorities activity. ] in Preisner Artur (ed), Czy istnieje uniwersalny standard praw człowieka? Kulturowe i cywilizacyjne uwarunkowania statusu jednostki [Is there a universal standard of human rights? Cultural and civilizational conditioning of the status of an individual] (2013) 3 Zeszyty Luksemburskie

Tabernacka Magdalena, Negocjacje $i$ mediacje $w$ sferze publicznej [Negotiations and mediations in public sphere] (Wolters Kluwer 2009) 
Magala Sławomir J., Kompetencje międzykulturowe [Cross-Cultural Competence] (Wolters Kluwer 2011) 55

Wóycicki Kazimierz, Czachór Waldemar., Jak rozmawiać z Niemcami? O trudnościach $w$ dialogu polsko-niemieckiego i jego europejskim wyzwaniu [How to talk with German. About Polish-German dialogue and its European Challenge] (Oficyna Wydawnicza Atut 2009) 